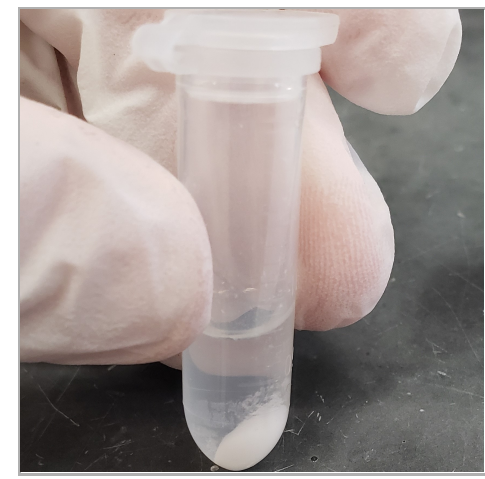

VERSION 3

MAR 01, 2019

\section{open $\partial$ ACcess}

DOI:

dx.doi.org/10.17504/protocol s.io.yrpfv5n

Protocol Citation: Kenneth Schackart, Kattika Kaarj 2019. E. coli K12 DNA Extraction. protocols.io https://dx.doi.org/10.17504/p rotocols.io.yrpfv5n

License: This is an open access protocol distributed under the terms of the Creative Commons Attribution License, which permits unrestricted use, distribution, and reproduction in any medium, provided the original author and source are credited

Protocol status: Working We use this protocol and it's working

Created: Mar 01, 2019

Last Modified: Mar 01, 2019

PROTOCOL integer ID:

21007

\section{(3) E. coli K12 DNA Extraction V.3}

\section{Kenneth Schackart ${ }^{1}, \quad$ Kattika Kaarj ${ }^{1}$}

${ }^{1}$ University of Arizona

\section{Yoon Lab}

$+\begin{aligned} & \text { Kenneth Schackart } \\ & \text { University of Arizona }\end{aligned}$

\section{ABSTRACT}

How to extract DNA from E. colik12 using Wizard® Genomic DNA Purification Kit by Promega ${ }^{\circledR}$.

I do not claim any credit for the development of this protocol. It has been adapted from the protocol detailed in: Wizard Genomic DNA Purification.pdf

\section{MATERIALS}

\section{MATERIALS}

\section{Wizard(R) Genomic DNA Purification Kit Promega Catalog \#A1620}

Additional materials:

- $1.5 \mathrm{~mL}$ microcentrifuge tubes

- Isopropanol, room temperature

- $70 \%$ ethanol, room temperature

-

\title{
Culture bacteria
}


1 Culture E. colik12 in $\mathrm{BHI}$ broth overnight.

\ $2 \mathrm{mg}$ lyophilized E. colik12 in \ $10 \mathrm{~mL}$ BHI broth.

\section{Pellet the cells}

2 Add $\triangle 1 \mathrm{~mL}$ cell suspension to $1.5 \mathrm{~mL}$ microcentrifuge tube.

3 Centrifuge at $13,000-16,000 \times g$ for $00: 02: 00$

4 Remove supernatant.

\section{Lyse nuclei}

5 Add $\triangle 600 \mu \mathrm{L}$ of Nuclei Lysis Solution.

6 Gently pipet until the cells are resuspended.

7 Incubate at $8^{\circ} 80^{\circ} \mathrm{C}$ on heating block for $00: 05: 00$ to lyse the cells.

8 Cool to room temperature. 


\section{Degrade RNA}

$9 \quad \operatorname{Add} \quad$ I $3 \mu \mathrm{L}$ RNase Solution to the cell lysate.

10 Invert 2-5 times to mix.

11 Incubate at $8^{\circ} 37^{\circ} \mathrm{C}$ for $00: 15: 00$ to $01: 00: 00$

12 Cool to room temperature.

\section{Precipitate proteins}

13 Add \ $200 \mu \mathrm{L}$ of Protein Precipitation Solution to the RNase-treated cell lysate.

14 Vortex vigorously at high speed for 00:00:20

15 Incubate on ice for 00:05:00 


\section{Harvest DNA}

17 Transfer the supernatant containing the DNA to a clean $1.5 \mathrm{~mL}$ microcentrifuge tube containing \ $600 \mu \mathrm{L}$ isopropanol.

Note

Some supernatant may remain in the original tube conatining the protein pellet. Leave this residual to avoid contaminating the DNA solution with the precipitated protein.

18 Gently mix by inversion until the thread-like strands of DNA form a visible mass.

\section{Wash and dry DNA}

19 Centrifuge at $13,000-16,000 \times g$ for $00: 02: 00$

20 Carefully pour off the supernatant and drain the tube on clean absorbent paper.

21 Add $\triangle 600 \mu \mathrm{L}$ of $70 \%$ ethanol and gently invert the tube several times to wash the DNA pellet.

22 Centrifuge at $13,000-16,000 \times g$ for $00: 02: 00$ 
23 Carefully aspirate the ethanol.

24 Drain the tube on clean absorbent paper and allow to air-dry for 10-15 minutes.

\section{Rehydrate DNA}

25 Add $\triangle 100 \mu \mathrm{L}$ of DNA rehydration solution to the tube.

26 Rehydrate by incubating the solution overnight at room temperature or $8^{\circ} 4^{\circ} \mathrm{C}$

27 Store DNA at $8^{\circ} 2^{\circ} \mathrm{C}$ to $8^{\circ} 8^{\circ} \mathrm{C}$ 